\title{
German Reunification in Historical Perspective
}

\author{
By \\ Robert M. Berdah1*
}

With his roots in the German-speaking world, for much of his distinguished career, Professor Richard Buxbaum has been a student of Germany in the context of international law. His scholarship has been recognized and honored by his colleagues in German Universities. As Dean of Berkeley's Department of Area and International Studies from 1993 to 1999, he consistently encouraged and supported the Center for German Studies at the University. This paper, dedicated to him, is a reflection of conversations he and I have had over the past few years concerning the future of Germany.

Throughout the history of both the German states that comprised Germany after 1949, it was taken as an article of faith that Germany would one day be reunified. Because its founders considered the Federal Republic of Germany (FRG) to be a temporary state, the preamble to their constitution, the Basic Law of May 23, 1949, declared that it was a transitional document. It guaranteed citizenship to Germans living outside the FRG upon their arrival there, thus intending to serve those Germans in the East who could not participate in its creation. In his inaugural address in 1960, the Federal Republic's second President, Heinrich Lübke, declared that German reunification "remains the question of our national life ... on which we are all united, irrespective of party and religious affiliation. In the long run, Germany will not remain separated, whether by absurd boundaries or by brutal disruption of personal ties." $\mathrm{He}$ considered the reunification of the two Germanys to be a "natural right."

For conservative politicians in the West, maintaining the vision of a reunified Germany served to cultivate support from the thousands of voters who had been expelled from the eastern territories lost to Germany at the end of World War II; while it was politically expedient, it also helped to forestall any further growth of right-wing nationalist sentiment. ${ }^{3}$ As late as the $1960 \mathrm{~s}$, placards with a map of pre-war Germany divided into three parts-West Germany, East Germany, and the lands east of the Oder-Neisse line-were

\footnotetext{
* Former Chancellor, University of California, at Berkeley, 1997-2004.

1. Gordon Craig, The Germans 303 (1982).

2. Id.

3. Id.
} 
posted throughout West Germany, with the slogan, "Dreigeteilt-Niemals!" ("Three-part division-Never!").

Undoubtedly, leaders of the German Democratic Republic (GDR) also looked forward to the ultimate reunification of Germany. For instance, in 1953, Socialist Unity Party (SED) leader, Walter Ulbricht, told his fellow party members, "We are for the unity of Germany, because the Germans in the west of our homeland are our brothers, because we love our fatherland, because we believe that the restoration of the unity of Germany has an irrefragable legal validity." 4 Central to Marxist doctrine was the belief in the inevitability of a revolution that would wipe away the capitalist structure of the West, opening the way to a unified socialist state in Germany. Perhaps ironically, even after the construction of the Wall between the East and West portions of Berlin, the 1963 program of the SED set "the restoration of German unity" as a goal for the party; continued division was merely attributed to the western powers "in conspiracy with West German monopoly capitalism." "The confidence expressed by communist leaders in the ultimate collapse of western capitalism continued into the last decade of the East German state's existence. In 1981, Eric Honecker, the leader of East Germany, warned West Germans:

One day Socialism will knock at your door, and, [sic] when the day comes on which the workers of the Federal Republic go about the socialist transformation of the Federal Republic of Germany, then the question of the unification of the two German States will be posed in completely new form. As to how we would decide then, there should be no question of doubt. ${ }^{6}$

Despite the persistent political rhetoric about a reunified Germany, and the initial conservative critique of Chancellor Willy Brandt's effort in the 1970s to normalize relations between the East and West German states (Ostpolitik), the political reality of divisions hardened over time. It was likely this hardening of the division between East and West that led few to think that reunification would be possible in the near future. Indeed, in 1988, Chancellor Kohl publicly expressed doubt that reunification would happen in his lifetime. Later, in January 1989, just months before its fall, Eric Honecker insisted the Wall would remain in place for 50 or 100 more years. ${ }^{7}$ Most Germans agreed; only 9 percent believed they would live to see reunification. ${ }^{8}$

Thus, the dramatic events of November 9, 1989, when exuberant East and West Germans danced together on the Berlin Wall, caught nearly all by surprise. $^{9}$ German reunification did not come as the consequence of political leadership on either side of the Wall; it came as a result of a truly peaceful popular revolt, the only such revolution in modern German history.

4. Id. at 307 .

5. Id.

6. Id. at 308 .

7. LEWIS J. EDINGER \& BRIGITTE L. NACOS, FROM BONN TO BERLIN: GERMAN POLITICS IN Transition 11, 12 (1998).

8. Id. at 11 .

9. Id. 
It began in May 1989, when Hungarian border guards began to permit East Germans to cross the border into Austria, from where they entered the Federal Republic. Other East Germans appealed to West German embassies in Budapest, Prague, and Warsaw. In September, Hungary officially opened its borders with Austria and the westward flood from the GDR began; 10 eight thousand crossed the border in the first twenty-four hours and by the end of the month 30,000 East Germans had fled to West Germany through Hungary and Austria. ${ }^{11}$ When the East German government restricted travel-first to Hungary, then to Czechoslovakia-mass protest demonstrations took place in major East German cities. ${ }^{12}$ The popular outrage demanded extensive reform. Honecker resigned on October 17, and the new government, led by Egon Krenz, attempted to regain control by revising travel restrictions without, in fact, opening the borders. ${ }^{13}$ More demonstrations followed until November 9, on which date a press announcement promised that applications for travel abroad would be approved immediately. ${ }^{14}$ A crowd of thousands overwhelmed officials at the Berlin checkpoints, who finally stopped stamping passports and allowed free passage to West Berlin. ${ }^{15}$ The demands for reform, under the banner "We are the people," quickly changed to demands for reunification, with the slogan "We are one people." 16

German reunification came about as a result of the people's actions. Yet, various political leaders could not resist the opportunity to take credit for reuniting Germany. Chancellor Kohl, hoping to claim a place in the pantheon of German heroes next to Bismarck, saw himself as the great unifier. Willy Brandt saw it as a culmination of the Ostpolitik he had initiated two decades earlier. Admirers of Presidents Reagan and Bush saw it as a consequence of their defeat of the Soviet Union in the Cold War. But, in fact, the hero of the story was the German people as a collective, who acted at nearly every stage of the process in advance of their leaders, who merely recognized the reality created by popular protest. $^{17}$

Three weeks after the Wall had fallen, and assured that the Soviet Union would not engage in aggressive diplomatic or military actions, Chancellor Kohl ignored popular demands for full German reunification by offering a cautious

10. See Mathias Reimann, Takeover: German Reunification Under a Magnifying Glass, 96 MICH L. REV. 1988, 1989 (1998) (“On September 11, Hungary punched a hole in the iron curtain through which East Germans could escape when it broke rank with the Warsaw Pact states and opened its border with Austria. So many took advantage of the opportunity that the resulting hemorrhage threatened the very survival of the GDR.").

11. Frank Tipton, A History OF MODERN GERMANY SinCE 1815, 619 (2003)

12. Id. at 619-20.

13. These attempted reforms failed to quell the hunger for freedom and democracy. See Reimann, supra note 10, at 1989 ("[I]t tumed out that all efforts to save the GDR-mocked by English speakers as the 'Gradually Disappearing Republic'-in its current form had come too late.").

14. TIPTON, supra note 11 , at 620

15. Id.

16. Id. at 622

17. See generally KonRad JaRAuSCH, THE RUSH TO GERMAN UNITY (1994). 
ten-point proposal to gradually link the two German states together. This plan would proceed so long as the East German government continued on a course of reform. ${ }^{18}$ His boldest proposal called for "confederate structures" that would have continued to recognize East German sovereignty; ${ }^{19}$ for Kohl, full governmental unity remained a distant vision. In both the East and the West, where increasing majorities of the people favored reunification, popular events overtook political leadership as the flow of people continued, with 138,000 moving westward in the first two months of $19900^{20}$ In July, the monetary union of both states took place, further eroding the legitimacy of the East German government. Moderate political voices in the GDR, who hoped to retain a separate state based on socialist principles, lost all leverage. In the discussions for a Treaty of German Unity that began in July 1990, the West German Minister of Interior, Wolfgang Schäuble, made it clear that reunification would be undertaken on terms defined by the FRG. He bluntly declared:

This is the accession of the German Democratic Republic to the Federal Republic of Germany and not the reverse. We want to do everything for you. You are cordially welcome. We do not want to trample coldly 21 your wishes and interests. But this is not the unification of two equal states. 21

The treaty was ultimately signed on August 31, and the two states became one on October 3,1990.22

The fall of the Berlin Wall was welcomed throughout the West for all that it represented: the end of a dictatorship, the disintegration of the east bloc, the triumph of market capitalism, and the end of the Cold War. Not everyone, however, was completely enthusiastic about German reunification. A French observer noted that:

Germany, a big nation, is again becoming a great nation .... [A]ll it lacks is the military arm. From the height of its power, its industrialists and merchants are looking far beyond the West, at the wide world. And France looks at Germany. It is the season of suspicion-thoroughly foreseeable after all. ${ }^{23}$

Other public figures, many of whom aggressively worked to oppose the Soviet Union, nevertheless hesitated to approve of the idea of German reunification. Margaret Thatcher openly expressed her disagreement with Kohl's plans. ${ }^{24}$ The British Trade and Industry Secretary, Nicholas Ridley, spoke strongly against Germany's hegemony in the European Economic Community (EEC). ${ }^{25}$ At a conference between Prime Minister Thatcher and a

18. TIPTON, supra note 11 , at 662 .

19. Id.

20. Id. at 623 .

21. Id. at 624 .

22. Id.

23. EDINGER \& NACOS, supra note 7, at 10-11.

24. See Evgenios Michail, After the War and After the Wall: British Perceptions of Germany Following 1945 and 1989, 3 University of Sussex Journal of Contemporary History 7 (2001), available at http://www.sussex.ac.uk/history/documents/3._michail_after_the_war_and_after_the_ wall.pdf (last visited April 26, 2005).

25. Id. 
group of British and American historians in March 1990, it was observed that Germany had succeeded in its century-old objective of dominating Europe, against which Britain had fought two costly wars. ${ }^{26}$ In Germany itself, a number of liberal intellectuals, including Jürgen Habermas and Günter Grass, expressed reservations about reunification.

Undeniably, German reunification revived persistent questions about continuity and change in Germany. It pushed to the surface, once again, the multidimensional "German question." In the context of international relations in Europe, the German question was whether Germany, with the largest population, most robust economy, and potentially the strongest military, would be fully integrated into Europe and provide stability, or whether it would pursue its traditional aim of establishing hegemony over the continent.

But in the context of German politics, the "German question" was whether the burden of its history had been overcome and the residue of the past abandoned. In no other country has the effort to come to terms with the past been as much a part of the contemporary discourse as in Germany; the memory of the Holocaust and the tyranny of the Nazi regime cast a deep shadow over all discussions of German history. In the 1980s, the so-called Historikerstreit (historian's conflict) erupted when conservative historian Ernst Nolte argued that it was time to reassess German guilt for the Holocaust and the Nazi regime. $^{27}$ He saw the roots of the Holocaust not in German anti-Semitism or Nazi ideology, but in Germany's defense against Bolshevism and Russian aggression. "Auschwitz is not primarily a result of traditional anti-Semitism," he wrote. "It was in its core not merely a 'genocide,' but was above all a reaction born out of the anxiety of the annihilating occurrences of the Russian Revolution." 28 Jürgen Habermas responded to Nolte, criticizing him for offering Germans a history that would alleviate their sense of guilt and for practicing a selective history that focused on the sufferings of Germans without recognizing their own responsibility. ${ }^{29}$ The ensuing debate, involving numerous historians of Germany, took on more compelling political meaning in the context of German reunification, for the control of the future was, in part, predicated on who controlled the past.

Historical references to the Weimar Republic sprang to mind when skinheads, radical right-wing groups, and neo-Nazis acted out their xenophobia and intolerance by harassing foreign refugees. Their threatening behavior, parroting the Weimar street gangs and Nazi behavior by declaring the former GDR town of Hoyerswerda to be a "Foreigner Free Zone," prompted calls for tough action by the government.

In examining the prospects for the new Germany, it is fair to ask whether

26. Id.

27. Benjamin B. Weber, Shades of Revisionism: Holocaust Denial and the Conservative Call to Reinterpret German History, in 6 History Review (1994).

28. Id.

29. TIPTON, supra note 11 , at 607 . 
the basic lineaments of the old Germany-not merely the Third Reich of Hitler, but also Bismarck's Second Reich-have been set aside. In this respect, it is instructive to examine the historical forces-above all anti-democratic authoritarianism, German nationalism, and Prussian militarism-that combined to unify Germany in 1871, and compare them to those elements present in 1990.

The first broadly popular expression of the impulse for German national unification came during the revolutions of 1848 . These revolutions, happening nearly simultaneously in Western and Central Europe, were driven by liberal and national ideals, which were both seen as forces of liberation. Liberalism sought to overthrow the constraints of the traditional order dominated by the nobility while introducing constitutional government; nationalism sought to allow people bound together by common language and culture to form national states reflecting those commonalities. Individual self-realization depended upon national self-realization. Thus, proponents of German nationalism, lacking a common political experience, defined the nation by its cultural and ethnic dimensions - a common people, divided into separate states and principalities, seeking a common national state. But the revolutions of 1848 failed in Germany partly because of the conflict between the national claims of Germans and those of other nationalities within the boundaries of the German states. Monarchical rule recovered.

It was Bismarck's genius to recognize that nationalism was not inherently connected to liberalism, that it could be detached from its alliance with liberalism and be put to the service of conservative ends. This is what he meant with his famous statement of 1863: "Not through speeches and majority decisions will the great questions of the day be decided-that was the great mistake of 1848 and 1849 - but through iron and blood."30 In three successful wars, 1864, 1866, and 1870-71, he united Germany under Prussian domination, ${ }^{31}$ forcing liberal nationalists to choose between their liberal ideals and their national ideals. They accepted national unifications at the expense of a liberal constitutional government, acceding to a Germany united under Prussian monarchical authority. The German constitution provided a parliament, but the Chancellor and other ministers remained responsible only to the Emperor. During the first two decades of the German Empire, Bismarck repeatedly confronted the national liberals with the choice between their nationalism and their liberalism, knowing they would choose the former. First, he exploited their anti-clericalism in the Kulturkampf to suppress the Catholic elements dissatisfied at being absorbed into a Protestant nation. Then, he employed their fear of socialists to attack the socialist party as an enemy of the state. ${ }^{32}$

Germany's stunning military victories over Austria and France in the wars of unification also laid the foundation for the militarism that characterized the German Empire, especially after 1890 under Emperor William II. The defeat of

30. TIPTON, supra note 11 , at 119.

31. Id. at 120 .

32. See generally id. 
France and the seizure of Alsace-Lorraine created the enduring French-German enmity that ultimately surrounded Germany with enemies and prompted the arms race leading up to World War I. German society became suffused with military values and deference to the army.

The Nineteenth Century unification of Germany may consequently be described as a revolution from above. It was based on a combination of an authoritarian monarchy, illiberal constitutionalism, German nationalism, and Prussian militarism. As a result, Germany entered the modern industrial era and became the dominant economic and military force in Europe with a social structure that retained a dominant aristocracy and military caste. German industry competed aggressively for markets under the protection of this conservative, authoritarian national state. This social, economic, and political constellation constituted what historians of Germany have called the German Sonderweg - the German "special route" to modernization. The continued domination of Germany by this pre-modern structure has been seen as setting the stage for the tragedies of the twentieth century.

Regardless of whether one believes that German development was unique, or that it laid the foundation for the disasters of the twentieth century, the circumstances of German reunification at the end of the twentieth century were vastly different. Consequently, the course which Germany is likely to follow will be very different.

German reunification took place in an entirely different geopolitical framework than any that had existed since Germany was first unified in 1871 . At the end of the nineteenth century, the national state was the primary agency of international interaction and competition; it was the primary object of allegiance. The decades that bracketed the turn of the twentieth century were the heyday of nationalism. By contrast, the decades bracketing the turn of the twenty-first century have witnessed strides toward a unified Europe and a structural transformation entailing the internationalization of financial markets, labor markets, and production. This transformation has weakened the national state and, in a sense, the primacy of the economic state has replaced that of the political state. Germany has emerged from reunification as a great power, but in an entirely different setting. Its economic power will be exercised through trans-European institutions.

It is notable that, as was the case after 1871 , German reunification did not result in a fully integrated society. Throughout the provinces of the former GDR, the early ebullience over reunification ultimately disappeared in the harsh reality of life in new circumstances. With the closure of their uncompetitive industries, easterners encountered staggering levels of unemployment. Similar conditions exist in some locations today. More than a decade after reunification, income and employment levels in the East remained well below those in the West. Easterners felt "Deceived and Sold Out," as one slogan put it. ${ }^{33}$ They

33. EDINGER \& NACOS, supra note 7, at 18. 
expressed resentment at having been "colonized" by West Germany. ${ }^{34}$ Some even expressed nostalgia for the GDR, referred to as "Ostalgie," in visible ways. $^{35}$

To their credit, German leaders refrained from exploiting intense nationalism or fear of foreigners, even when faced with challenges over methods to achieve greater integration of the two Germans states. For example, the debate over the nationality law, the definition of citizenship, and what it meant to be German, challenged the traditional assumptions about the composition of the German nation. As we have noted, German nationalism developed prior to the creation of a German nation state; until 1871, the German nation was an ethnic, cultural, and linguistic entity, but not a political reality. Nationality was considered a matter of descent and blood, based on the principle of jus sanguinus; in contrast, in France and the United States, the principle of jus soli prevailed, in which citizenship or nationality was derived from the place of birth. While the principle of jus soli is culturally inclusive, the principle of jus sanguinus is culturally exclusive.

Initially, after 1871, the various German states comprising the Second Empire retained their own laws on citizenship, although they were all derived from the principle of jus sanguinus. In 1913, Germany adopted a uniform law defining nationality. This law had two fundamental purposes: first, to include all Germans living abroad in the colonies (even those living in the United States) who chose to return to Germany; and second, to exclude the growing immigrant population in Germany, primarily migrant workers from Poland settling in the industrial Ruhr valley, from national citizenship. The law thus provided an exclusionary, ethno-cultural definition consistent with the principle of jus sanguinus. This exclusionary principle provided the foundation for the explicitly exclusionary anti-Jewish laws during the Nazi era. Jus sanguinus remained the basis for German nationality laws until after German reunification.

Several factors made it necessary to address the question of citizenship in the new German state. First, a large number of non-German citizens now lived in Germany, many of whom had immigrated to West Germany decades before as "guest workers" and whose children had grown up there. Berlin, for example, had become the third largest Turkish city in the world. Others had come to Germany from eastern and southeastern Europe in search of political asylum. By the $1990 \mathrm{~s}$, foreigners comprised 10 percent of the population of Germany. Moreover, the European Union had introduced the concept of "European citizenship," and allowed the free movement of people across national boundaries. Finally, the declining birthrate of Germans meant that to sustain the economy, Germany would need to attract 300,000 immigrants annually. However, the conservative Christian Democratic Union/Christian Social Union government opposed changes in nationality law, insisting that nationality was a

34. Id.

35. See generally DAPHNE BERDAHL, WHERE THE WORLD ENDED: REUNIFICATION AND IDENTITY IN THE GERMAN BORDERLAND (1999). 
matter of blood descent. It was therefore not until 1998, when the coalition led by the Social Democratic Party of Germany (SPD) came to power, that fundamental changes could be considered. The new law that came into effect on January 1, 2000, set aside the principle of jus sanguinus and adopted jus soli for the first time in German history. It allowed children born in Germany of nonGerman parents to become German citizens; children granted citizenship under the provisions of this law could maintain dual citizenship until age twenty-three, at which point they were required to choose their nationality. The law shortened the period of time required for naturalization from fifteen years to eight years. As a concession to the traditional cultural definition of nationality, persons seeking German citizenship were required to pass examinations on German language and culture.

This nationality law was a substantial break with the German past; it brought German practice into closer alignment with that of Western Europe and the United States, and it demonstrated Germany's willingness to combat the fear of foreigners that had dominated so much of its past.

Although many feared that German rearmament might once again lead to the resurgence of a militarist spirit in Germany, considerable evidence suggests that the historical record of two world wars and the total destruction of Germany in 1945 have broken the thread of militarism in German history. The strength of German pacifism during the Cold War could easily be explained by the fact that any hostilities between NATO and the Soviet Union would lead to a war fought initially on German soil. But pacifist attitudes in Germany have continued since the end of the Cold War and German reunification. Although German troops have participated in various peace-keeping missions under UN general auspices, and Germany provided material support to the broad coalition in the Gulf War of 1991, a significant percentage of Germans opposed the war. As the war began, 200,000 demonstrators from all parts of Germany gathered in Bonn to protest the war. These demonstrations, however, were dwarfed by the anti-war demonstrations directed against the American invasion of Iraq in 2003. The anti-war sentiment was so strong in Germany that Chancellor Schröder was reelected in 2002 because of his opposition to the American determination to invade Iraq, despite widespread dissatisfaction with Germany's sagging economy. ${ }^{36}$ Behind these views lies a growing suspicion that the United States itself has become a reckless military presence in the world.

The half century of stable democracy in West Germany, now complemented by the popular movement in East Germany that ultimately produced the new German state, suggests that democratic values have taken root in Germany, overturning the long tradition of authoritarianism. Skeptics and pessimists point to the extreme right-wing parties and the nationalist expressions

36. See German Politics: Playing it Long, THE ECONOMIST, 10/30/04, at 31 ("In his first six years in office, Mr Schröder seemed a lightweight who changed course easily. Yet his opposition to the Iraq war (resented in Washington but liked at home) and his refusal to ditch labour-market reforms - the so-called Hartz laws-have changed his image."). 
of xenophobia, ${ }^{37}$ suggesting that democratic values may not have sunk roots as deeply as we would wish. They also point out that the German commitment to democratic values has not been tested by crises of the magnitude of the hyperinflation and the Depression that contributed to the collapse of the Weimar Republic. It is admittedly true that German democracy has not yet been tested by crisis. Yet, it is also true that the free institutions and civil liberties essential to democracy are always vulnerable in crises, as the history of the United States demonstrates from the Civil War, to the internment of Japanese, and to the Patriot Act. Fear and uncertainty nearly always undermine confidence in democratic values. But the anti-democratic forces that characterized the first German reunification-authoritarianism, militarism, and exclusionary nationalism-do not fundamentally characterize the reunified Germany, and there is every reason to believe its democratic system is as stable and secure as any in the world today.

37. See Neo-Nazis Hi-Jack Commemoration, DAILY POST, 2/14/05, at 10 ("The 60th anniversary of the World War II Allied bombing of Dresden was overshadowed yesterday by one of the largest public, post war gatherings of neo-Nazis. [T] he milestone was upstaged by a march of around 5,000 neo-Nazis through the streets of the eastem German city."); but see Tony Czuczka, Germany Muzzles Neo-Nazi Rallies, ST PAUL PIONEeR Press, 3/12/05, at 6A ("[T] he changes [in German law] are meant to make it easier for authorities to ban neo-Nazi gatherings near memorials to victims of the Nazis, such as former concentration camps . ... Anyone who publicly 'condones, glorifies or justifies' the Nazis risks fines or up to three years in prison."). 